\title{
The Effectiveness of Biological Products and Micronutrient Fertilizers use in Row Crops Cultivation
}

\author{
Maria Belik $^{1, *}$, Svetlana Sviridova $^{1}$, and Tatyana Yurina $^{1}$ \\ ${ }^{1}$ Federal State Bugetary Scientific Institution, KubNIITiM, 15, Krasnaya Str., 352243 Novokubansk, \\ Krasnodar Territory, Russia
}

\begin{abstract}
The results of field studies of the use of biological products and microfertilizers in the cultivation of corn for grain and sunflower in the production conditions of the Krasnodar Region are presented. Indicators of a comparative assessment of economic and new schemes for the application of fertilizers and plant protection products from the point of view of agrotechnical and economic efficiency are given.
\end{abstract}

\section{Introduction}

At present, the protection of plants from diseases caused by various pathogens is an economically and socially significant problem. The main method of plant protection is the use of chemicals that have a number of serious disadvantages. The use of biological plant protection products is becoming more and more urgent [1-3]. To date, in Russia, only $0.3 \%$ of agricultural land is processed with biological products [4].

The use of fertilizers has the greatest impact on the formation and development of plants in the cultivation of row crops. Optimization of plant nutrition, namely the use of modern biological products and microelements during the growing season, contributes to an increase in the yield of corn and sunflower grain [5-7].

Biological products are used for preliminary inoculation of seeds, spraying of plants during the growing season in order to improve nutrition, increase resistance to pathogens, increase yields and improve the quality of agricultural products [8-10].

Recent studies indicate that the most effective form of trace elements for plants are complex compounds in the form of chelates (organic intracomplex compounds of cyclic structure, containing an ion of any metal in their molecule). An important feature of chelates is the manifestation of biochemical activity due to the content of amino acid fragments in their composition. This allows us to consider them as compounds that provide plants with better availability of trace elements that contribute to their greater productivity. Trace elements in a chelated form have a number of valuable properties: they are highly soluble in water, highly stable in a wide range of acidity ( $\mathrm{pH}$ values), are well adsorbed on the surface of leaves and in the soil, they are not destroyed by microorganisms for a long time, and are

\footnotetext{
${ }^{*}$ Corresponding author : mashabelik@yandex.ru
} 
well combined with various pesticides. Trace elements, when introduced into the soil, contribute to the conversion of inaccessible trace elements into a biologically active form. Such microelements are water-soluble organic salts and are practically not fixed in the soil absorbing complex, remaining available for plants for a long time [11-13].

Currently, a large number of new types of biological preparations and fertilizers have been developed with different doses of microelements and various methods of their application for row crops cultivated using intensive technologies. The choice of the most effective drugs for certain crops and specific economic conditions is an urgent and urgent task.

In recent years, Russian scientists have created biological preparations, the use of which ensures an increase in the yield of agricultural crops. The main mechanisms of action of microorganisms on plants are as follows: improving nitrogen nutrition, optimizing phosphorus nutrition, stimulating growth and development, suppressing phytopathogens (controlling the development of diseases and reducing plant damage), increasing the utilization of nutrients from fertilizers and soil, increasing resistance to stress conditions (lack of precipitation, unfavorable temperatures, high acidity, salinization or soil pollution with substances of various natures) [14].

The relevance of the studies carried out by the specialists of the Novokuban branch of the Federal State Budgetary Scientific Institution "Rosinformagrotech" (KubNIITiM) is to substantiate the effectiveness of the use of biological preparations and fertilizers with microelements produced by Biotechagro LLC as leaf treatments in the cultivation of row crops.

The purpose of this work is to study the effect of various schemes for the introduction of biological preparations and fertilizers with microelements on the yield of row crops (corn for grain, sunflower).

\section{Materials and methods}

Materials for industrial research (Table 1) were provided by "Biotehagro" LLC (Timashevsk), which produces biological products based on living, beneficial microorganisms, and develops schemes for the effective use of these drugs in agriculture.

Table 1. Brief characteristics of drugs

\begin{tabular}{|l|l|}
\hline \multicolumn{1}{|c|}{ Drug } & \multicolumn{1}{c|}{ Type } \\
\hline $\begin{array}{l}\text { BFTIM KS-2, } \\
\text { Zh }\end{array}$ & biofungicide \\
\hline CMS-1 & microfertilizer \\
\hline Humat +7 & fertilizer based on humic acids (liquid concentrate) \\
\hline Helios Silicon & $\begin{array}{l}\text { liquid mineral fertilizer with a maximum concentration of silicon in } \\
\text { the form of silicon dioxide of a special form of processing }\end{array}$ \\
\hline
\end{tabular}

The research work was carried out in accordance with the methodology of field experience in agricultural crops of corn for grain, sunflower, developed jointly with representatives of the "Biotehagro" LLC, and taking into account their recommendations on the timing and doses of the drugs used in the experiment (Table 2), and also in compliance with certain methodological requirements (typicality, principle of single difference, etc.) according to the instructions for conducting the field experiment by B.A. Dospekhova [15].

Table 2. Experimental options for experimental sowing of row crops 


\begin{tabular}{|c|c|c|}
\hline $\begin{array}{l}\text { Processing date } \\
\text { and plant phase }\end{array}$ & Option 1 (control) & Option 2 (Biotehagro) \\
\hline \multicolumn{3}{|c|}{ Corn for grain } \\
\hline $\begin{array}{c}29.05 .20 \\
\text { sheet processing } \\
\text { in the phase of 4-6 } \\
\text { leaves }\end{array}$ & $\begin{array}{c}\text { zinc sulfate }(1.0 \mathrm{~kg} / \mathrm{ha})+ \\
\text { Potassium humate }(0.5 \mathrm{l} / \mathrm{ha})\end{array}$ & $\begin{array}{c}\text { BFTIM, KS-2, Zh }(2.0 \mathrm{l} / \mathrm{ha})+ \\
\text { CMS-1 }(1.0 \mathrm{~g} / \mathrm{ha})+ \\
\text { Humate }+7(1.0 \mathrm{l} / \mathrm{ha})\end{array}$ \\
\hline \multicolumn{3}{|c|}{ Sunflower } \\
\hline $\begin{array}{c}29.05 .20 \\
\text { sheet processing } \\
\text { in the phase of 4-6 } \\
\text { leaves }\end{array}$ & & $\begin{array}{c}\text { BFTIM, KS-2, Zh (3.0 l/ha)+ } \\
\text { Helios Silicon }(0.5 \text { l/ha })\end{array}$ \\
\hline
\end{tabular}

For the purity of the experiment, experimental plots were laid for each crop within a separate field for the predecessor of winter wheat, all technological operations were identical and corresponded to the generally accepted schemes of cultivation of these crops.

A mid-season hybrid of corn for grain "Pioneer P9241 (P9241)" (FAO 340) from the American company Pioneer, included in the State Register for the North Caucasus region. The plant is medium-sized, strong stem increases lodging resistance. Excellent resistance to stress and drought. A hybrid of maize with an innovative system of resistance to blister smut, fusarium on the cob and helminthosporiosis.

A mid-early hybrid of the "Pioneer P64LL125" sunflower of the Pioneer linoleic type with a high oil content. It has high indicators of drought resistance, well-developed root system. A large number of seeds are formed in the basket of the plant. Differs in high productivity rates and excellent drought tolerance. Perfectly adapts to any soil and climatic conditions. Sunflower hybrid with an innovative system of broomrape resistance "System-2" and root lodging. Good tolerance to leaf and basket diseases. The growing season is 105-115 days, the yield potential is $49 \mathrm{c} / \mathrm{ha}$, the plant height is $180 \mathrm{~cm}$, the basket is convex, the oil content is $50 \%$, the weight of 1000 seeds is $60 \mathrm{~g}$.

\section{Results and discussion}

\subsection{Pre-harvest monitoring options}

According to the developed methodology for a comparative assessment of the variants of the experiment, before harvesting, the crops were monitored by the variants of the experiment (tables 3,4 ). To do this, on the counting sites $10 \mathrm{~m}$ long, each two rows wide, a complete analysis, counting and measurement of plants (in triplicate) were carried out.

Table 3. Results of pre-harvest survey of grain corn crops 


\begin{tabular}{|l|c|c|}
\hline \multirow{2}{*}{ Indicator name } & \multicolumn{2}{|c|}{ Indicator value by experience options } \\
\cline { 2 - 3 } & № 1 k (Control) & $\begin{array}{c}\text { No 2 } \mathbf{k} \\
\text { (Biotehag } \\
\text { ro) }\end{array}$ \\
\hline Plant height, cm & 288.1 & 298.0 \\
\hline Stem diameter, mm & 22.5 & 23.2 \\
\hline Height of the lower ear, cm & 116.5 & 115.5 \\
\hline Ear length, cm & 16.0 & 17.0 \\
\hline Ear diameter, mm & 42.5 & 42.8 \\
\hline
\end{tabular}

Table 4. Results of pre-harvest inspection of sunflower crops

\begin{tabular}{|l|c|c|}
\hline \multirow{2}{*}{ Indicator name } & \multicolumn{2}{|c|}{ Indicator value by experience options } \\
\cline { 2 - 3 } & № 1p (Control) & № 2p (Biotehagro) \\
\hline Plant height, $\mathrm{cm}$ & 218.5 & 224.8 \\
\hline Basket height, $\mathrm{cm}$ & 202.9 & 199.0 \\
\hline Basket diameter, cm & 17.0 & 18.2 \\
\hline Stem diameter, $\mathrm{mm}$ & 16.2 & 16.8 \\
\hline
\end{tabular}

As a result of a comparative assessment with the control variant, differences in the biometric parameters of plants and in the general state of crops were revealed.

For corn for grain for option $2 \mathrm{k}$ (Biotechagro) in comparison with option No. $1 \mathrm{k}$ (control):

- plant height is $9.9 \mathrm{~cm}$ or $3.4 \%$ more;

- the average thickness of the stem at the base of the plants is $0.6 \mathrm{~mm}$ or $3.7 \%$ higher;

- the average height of the lower ear is less by $1.0 \mathrm{~cm}$ or $0.8 \%$;

- the length of the cob increased by an average of $1.0 \mathrm{~cm}$ or $6.3 \%$;

- the ear diameter has increased by an average of $0.3 \mathrm{~cm}$ or $0.7 \%$.

For sunflower for option $2 \mathrm{p}$ (Biotehagro) in comparison with option $1 \mathrm{p}$ (control):

- plant height is $6.3 \mathrm{~cm}$ or $2.9 \%$ more;

- the average height of the arrangement of baskets is lower by $3.9 \mathrm{~cm}$ or $1.9 \%$;

- the average diameter of a sunflower basket is $1.2 \mathrm{~cm}$ or $7.1 \%$ higher;

- the average diameter of the plant stem is $0.6 \mathrm{~mm}$ or $3.7 \%$ more.

\subsection{Yield assessment}

Evaluation of the yield according to the variants of the experiment was carried out during harvesting by direct combining in one day: for corn for grain on 09/08/2020 with an average grain moisture of $11.4 \%$, for sunflower - on August 26, 2020 with an average grain moisture of $7.0 \%$. The actual yield (table 5) was determined by the amount of harvested grain from the accounting plot harvested by the same combine.

Table 5. Indicators of yield and quality of grain by options of experience

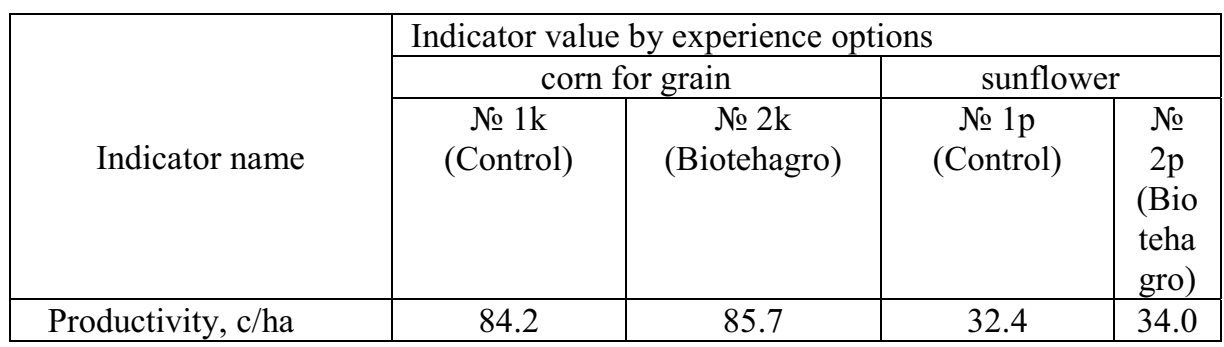




\begin{tabular}{|c|c|c|c|c|}
\hline \multirow[b]{3}{*}{ Indicator name } & \multicolumn{4}{|c|}{ Indicator value by experience options } \\
\hline & \multicolumn{2}{|c|}{ corn for grain } & \multicolumn{2}{|c|}{ sunflower } \\
\hline & $\begin{array}{c}\text { № } 1 \mathrm{k} \\
\text { (Control) }\end{array}$ & $\begin{array}{c}\text { № 2k } \\
\text { (Biotehagro) }\end{array}$ & $\begin{array}{c}\text { № } 1 \mathrm{p} \\
\text { (Control) }\end{array}$ & $\begin{array}{c}\text { № } \\
2 \mathrm{p} \\
\text { (Bio } \\
\text { teha } \\
\text { gro) }\end{array}$ \\
\hline Mass 1000 grains, $g$ & 283.40 & 292.58 & 54.84 & $\begin{array}{c}59.6 \\
9\end{array}$ \\
\hline
\end{tabular}

As a result of harvesting, the actual yield of corn grain in option No. 2k (Biotehagro) amounted to $85.7 \mathrm{c} / \mathrm{ha}$, which is $1.5 \mathrm{c} /$ ha or $1.8 \%$ higher than the control option. The advantage in the weight of 1000 grains $(292.58 \mathrm{~g})$ also prevailed in variant No. $2 \mathrm{k}$ (Biotehagro), which is $9.18 \mathrm{~g}$ or $3.3 \%$ higher than the indicator of the control variant.

The yield of sunflower in option $2 \mathrm{p}$ (Biotehagro) was $34.0 \mathrm{c} / \mathrm{ha}$, which is higher than the control option by $1.6 \mathrm{c} / \mathrm{ha}$ or $5.0 \%$. The advantage in the weight of 1000 grains $(59.69 \mathrm{~g})$ also prevailed in option $2 \mathrm{p}$ (Biotechagro), which is $4.85 \mathrm{~g}$ or $8.9 \%$ higher than the control option. 3.3 Economic evaluation of technology options

Let us analyze the indicators of economic efficiency (table 6) of the introduction of drugs produced by OOO Biotehagro (option No. 2) in comparison with option No. 1 (control).

Table 6. Indicators of economic efficiency of technology options

\begin{tabular}{|c|c|c|c|c|}
\hline \multirow[b]{3}{*}{ Indicator name } & \multicolumn{4}{|c|}{ Indicator value by experience options } \\
\hline & \multicolumn{2}{|c|}{ corn for grain } & \multicolumn{2}{|c|}{ sunflower } \\
\hline & $\begin{array}{c}\text { № 1к } \\
\text { (Control) }\end{array}$ & $\begin{array}{c}\text { № 2K } \\
\text { (Biotehagro } \\
\text { ) }\end{array}$ & $\begin{array}{c}\text { № 1ா } \\
\text { (Control) }\end{array}$ & $\begin{array}{c}\text { № 2ח } \\
\text { (Biotehagro } \\
\text { ) }\end{array}$ \\
\hline $\begin{array}{l}\text { Cost of realized } \\
\text { products, thousand rubles }\end{array}$ & 28628.00 & 29138.00 & $\begin{array}{c}220449.6 \\
0\end{array}$ & 23133.60 \\
\hline $\begin{array}{l}\text { Working capital, thousand } \\
\text { rubles, }\end{array}$ & 6718.68 & 6871.89 & 3782.64 & 4023.80 \\
\hline including: & 1704.23 & 1704.23 & 1281.94 & 1289.83 \\
\hline - fuel & 2920.26 & 2920.26 & 1868.89 & 1868.89 \\
\hline - seed & 1137.94 & 1150.90 & 0 & 72.90 \\
\hline $\begin{array}{l}\text { - fertilizers } \\
\text { - plant protection products }\end{array}$ & 956.25 & 1096.50 & 631.80 & 792.18 \\
\hline $\begin{array}{l}\text { Cost of production, thousand } \\
\text { rubles }\end{array}$ & 11084.20 & 11237.42 & 6170.38 & 6518.25 \\
\hline Profit, rub/ha & 41279.52 & 42119.02 & 48995.62 & 51281.96 \\
\hline $\begin{array}{l}\text { Additional costs for drugs in } \\
\text { comparison with economic } \\
\text { application, rub/ha }\end{array}$ & - & 360.49 & - & 1073.67 \\
\hline $\begin{array}{l}\text { Additional profit received due } \\
\text { to the introduction of drugs in } \\
\text { comparison with the economic } \\
\text { application, rub/ha }\end{array}$ & - & 839.50 & - & 2286.34 \\
\hline
\end{tabular}

In the variants of application of Biotechagro preparations, the profit per hectare was obtained higher: for corn for grain - by $839.5 \mathrm{rub} /$ ha or by $2.1 \%$, for sunflower - by 2286.3 $\mathrm{rub} / \mathrm{ha}$ or by $4.7 \%$. For both options, the additional profit received due to the introduction of 
drugs in comparison with the economic application is significantly higher than the additional costs.

\section{Discussion}

Analyzing the obtained results of the use of preparations produced by "Biotehagro" LLC (option 2) in production technologies for the cultivation of corn for grain and sunflower, we can conclude that there is a positive dynamics of improvement of such indicators as the length and diameter of the corn cob, the diameter of the sunflower basket. An increase in their values contributed to an increase in yield for grain corn by $1.5 \mathrm{c} /$ ha or $1.8 \%$, for sunflower - by 1.6 c/ha or $5.0 \%$.

The analysis of the results of the economic assessment showed that for corn for grain, the profit per hectare increases by $2.1 \%$ compared to the agricultural application, and the additional profit received from the increase in yield due to the use of drugs is $839.5 \mathrm{rub} / \mathrm{ha}$, which 2.3 times higher than additional drug costs. For sunflower, the profit per hectare increases by $4.7 \%$ compared to the agricultural application, and the additional profit received from the increase in yield due to the use of drugs is $2286.3 \mathrm{rub} / \mathrm{ha}$, which is 2.1 times higher than the additional costs for drugs.

\section{Conclusion}

Based on the results of experimental studies of various schemes for the use of biological preparations and micronutrient fertilizers from "Biotehagro" LLC in production technologies for cultivating a hybrid of corn for grain "Pioneer P9241" and a hybrid of sunflower "Pioneer P64LL125" Krasnodar Territory) established:

- the use of the preparations provides an increase in the grain corn yield by $1.8 \%$. The variant of application of Biotechagro preparations differs from the control one in the following: at the technological operation "Foliar dressing" by replacing the fertilizer with zinc sulfate with an insecticide BFTiM (2 1/ha) and micronutrient fertilization CMS (1 1/ha) and replacing the organic mineral fertilizer Potassium humate with a fertilizer based on humic acids Humate +7 (1 1/ha). The amount of additional profit amounted to $840 \mathrm{rub} / \mathrm{ha}$, which is 2.3 times higher than additional costs;

- the use of preparations provides an increase in sunflower harvest by $5 \%$. In the variant of applying Biotechagro preparations, foliar processing (in the phase of 4-6 leaves) of a tank mixture consisting of biofungicide BFTiM (3 $1 /$ ha) and liquid mineral fertilizer Helios silicon $(0.5 \mathrm{l} / \mathrm{ha})$ with a maximum concentration of silicon in the form of silicon dioxide in a special form of processing. The amount of additional profit amounted to $2,286 \mathrm{rub} / \mathrm{ha}$, which is 2.1 times higher than additional costs.

Thus, the results of the analysis provide prerequisites for the inclusion of schemes for the introduction of biological preparations and microfertilizers produced by "Biotehagro" LLC in the technology of cultivation of corn for grain and sunflower and in recommendations to agricultural producers of the Krasnodar Territory in order to improve and reduce the cost of production.

\section{References}

1. R. L. Rubin, Plant and Soil, 1/2, 309-323 (2017)

2. M. A. Holland, Journal of the Washington Academy of Sciences 1, 31-42 (2016)

3. P. Calvo, Plant and Soil, 1/2, 3-41 (2014) 
4. R.R. Azizbekyan, Biotechnology in Russia 5, 37-47 (2018)

5. Y. Shcatula, Sciences of Europe, 60-1, 3-10 (2020)

6. O. Sidorenko, 2 First Serbian forestry Congress, 172-173 (Belgrade, 2010)

7. O.V. Kyrychenko, Biotechnologia Acta 4, 40-52 (2015)

8. P. Feklistova, Biologically active preparations for plant growing: Scientific background, Recommendations, 189-191 (Minsk, 2020)

9. M. Pallabi, Consilience, 11, 41-61 (2014)

10. I.S. Agas'eva, M.V. Nefedova, E.V. Fedorenko, A.O. Mkrtchyan, A.S. Nastasii, V.Ya. Ismailov, Agricultural Biology 1(54), 101-109 (2019) doi: 10.15389/agrobiology.2019.1.101rus

11. S.D. Grishechkina, V.P. Ermolova, T.A. Romanova, A.A. Nizhnikov, Agricultural Biology 5(53), 1062-1069 (2018) doi: 10.15389/agrobiology.2018.5.1062rus

12. J.D. Van Mansvelt, S.K. Temirbekova, Agricultural Biology 3(52), 478-486 (2017) doi: 10.15389/agrobiology.2017.3.478rus

13. O.Yu. Kremneva, A.M. Asaturova, M.D. Zharnikova, G.V. Volkova, Agricultural Biology 1(50), 99-106 (2015) doi: 10.15389/agrobiology.2015.1.99rus

14. A.P. Kozhemyakov, Yu.V. Laktionov, T.A. Popova, A.G. Orlova, A.L Kokorina, O.B. Vaishlya, E.V. Agafonov, S.A. Guzhvin, A.A. Churakov, M.T. Yakovleva, Agricultural Biology 3(50), 369-376 (2015) doi: 10.15389/agrobiology.2015.3.369rus

15. B.A. Dospekhov, Metodika polevogo opyta, Book on Demand, 352 (Moscow, 2012) 